\title{
Herbicides with natural and synthetic biostimulants in spring wheat
}

\author{
Kinga Matysiak ${ }^{1 *}$ Wojciech Miziniak $^{1} \odot$ Sylwia Kaczmarek $^{1} \odot$ Roman Kierzek $^{1} \odot$ \\ ${ }^{1}$ Institute of Plant Protection, National Research Institute, Władysława Węgorka 20, 60-318, Poznań, Poland. E-mail: K.Matysiak@iorpib.poznan.pl. \\ ${ }^{*}$ Corresponding author.
}

ABSTRACT: Although the knowledge on agricultural using of biostimulants increases, there is still little information on their interactions with other chemicals i.e. herbicides. The aim of the study was to assess the influence of popular herbicides (MCPA + dicamba, dicamba + triasulfuron, florasulam+2,4-D) used with and without biostimulants based on seaweed extract (Kelpak) and nitrophenols (Asahi) on weed control efficiency, yield and quality of the crop. Field trial was carried out in the years 2014 and 2015 in the Institute of Plant Protection - National Research Institute in Poznan (Poland). The experiment was established on spring wheat cv. 'Torridon', in 4 replications, using randomized block design. In the experiment two variants of application were tested. In the first variant preparations (herbicide and biostimulant) were applied as tank mixtures at the crop growth stage BBCH 30 and in the second variant in some combinations herbicide application was followed by biostimulant used alone. Weather conditions had a profound impact on tested preparations activity. Addition of biostimulants to herbicide had not affected weed control efficacy but application of herbicide and biostimulant mixture revealed its influence on yield parameters of wheat. Biostimulants influenced yield quality parameters e.g. by enhancing gluten amount in grains.

Key words: biostimulant, seaweeds, algae extract, herbicides, tank mixtures, wheat.

Aplicação de herbicidas com bioestimulantes natural e sintético no trigo primavera

RESUMO: Embora o conhecimento sobre o uso agrícola de bioestimulantes aumente, ainda há pouca informação sobre suas interações com outros produtos químicos, como por exemplo, herbicidas. O objetivo desta pesquisa consistiu em avaliar o efeito dos herbicidas MCPA + dicamba, dicamba + triasulfuron + e florasulam $+2,4-D$, usados com bioestimulantes a base de extratos de algas marinhas (Klepak) e nitrofenóis (Asahi) sobre a eficiência do controle de plantas daninhas e o rendimento da produção das plantas cultivadas. Os estudos de campo foram realizados nos anos de 2014 e 2015 pelo Instituto de Proteção de Plantas - Instituto Nacional de Pesquisas em Poznań (Polonia). O experimento foi realizado na cultura do trigo, cultivar 'Torridon' com quatro repetições. Foram estudadas diferentes opções de mistura de herbicidas versus bioestimulantes que foram aplicados em mistura de tanque ou o bioestimulante foi aplicado três dias após a aplicação do herbicida. As condições climáticas afetaram o desempenho das misturas utilizadas. A adição de bioestimulante ao herbicida não modificou a eficiência do controle de plantas daninhas, mas revelou grande influência nos parâmetros de produtividade do trigo. O uso de bioestimulantes provocou a melhora da qualidade dos grãos, aumentando o teor de glúten.

Palavras-chave: bioestimulante, algas marinhas, herbicidas, aplicação combinada trigo de primavera.

\section{INTRODUCTION}

Obtaining stable, high quality yields requires both mitigating the adverse effects of biotic factors (weeds, diseases and insects) and protecting the crops against abiotic factors. During the vegetation season, crop plants are exposed to a number of stress factors resulting from unfavorable soil conditions or herbicides. While mitigating the adverse effects of pests is directly related to the level of plant protection, it is difficult to minimize the negative impact of abiotic factors.

The adverse impact of abiotic factors on crop yields can be mitigated by biostimulants, which improve the biochemical, morphological and physiological processes in crop plants. Among the large group of biostimulants, there are organic substances obtained from plant extracts, synthetic compounds and microelements that improve crop yields. Biostimulants are products that can modify physiological functions of plants, strengthen plant defenses against different biotic and abiotic stresses and improve nutrition efficiency. Usually they are known as 'plant conditioners' which help plants to adapt to unfavorable conditions. These plant conditioners suppress or eliminate plant growthlimiting factors affecting plant during its life. They protect plants and work differently from other plant 
protection products. They are also not fertilizers because their main function is not to deliver nutrients to the plant (VERKLEIJ, 1992; CALVO et al., 2014; PRZYBYSZ et al., 2014; DU JARDIN, 2015).

Currently, one of the most popular group of biostimulants in agriculture and horticulture are seaweeds. Seaweeds act on soils and plants by delivery of purified compounds, which include polisacharides, alginates, micro and macronutrients, sterols and hormones. They can be applied on soils, in hydroponic solutions or as foliar treatments. (STRIK et al., 2003; KHAN et al., 2009; CRAIGIE, 2011; DU JARDIN, 2015).

Another group of biostimulants are synthetic products based on phenolic compounds. The phenolic compounds can improve plant protection against stress conditions and it can hold sustainable crop yield. Some authors state that they can significantly stimulate plant growth and development even in stress less conditions by enhancing IAA activity and increasing in the activity of nitrate reductase, an important enzyme in nitrogen metabolism (PRZYBYSZ et al., 2010; PRZYBYSZ et al. 2014).

Generally, an activity of biostimulants in many different crops is well enough known but they are known mostly as substances applied independently of other plant protection products. There is only few scientific reports on mix application biostimulants with pesticides; i.e, herbicides. This study evaluates foliar application of natural (seaweeds) and syntetic (phenols) biostimulants applied separately and as a tank mixtures with popular herbicides in enhancing yield and grain quality of spring wheat.

\section{MATERIALS AND METHODS}

\section{Trial conditions}

Field experiment was carried out in the years 2014 and 2015 in the Experimental Station in Torun $\left(52^{\circ} 12^{\prime} 0^{\prime \prime} \mathrm{N} 17^{\circ} 27^{\prime} 0^{\prime \prime} \mathrm{E}\right)$ belonged to the Institute of Plant Protection - National Research Institute in Poznan. The experiment was established in randomized block design in 4 replications on spring wheat cv. Torridon. The surface area of plots was $12 \mathrm{~m}^{2}$ and the width row spacing was of $-11 \mathrm{~cm}$. In both seasons the fore crop was sugar beet. Wheat sowing was performed on $30^{\text {th }}$ of March 2014 and $6^{\text {th }}$ of April 2015. The experiment was conducted in grey-brown podzolic soil, of $\mathrm{pH} 5.6-5.8$ and a content of organic matter of 1.7-1.8\%, depending on year of research. Mineral fertilization was used: $\mathrm{N} 140 \mathrm{~kg} \cdot \mathrm{ha}^{-1}, \mathrm{P}_{2} \mathrm{O}_{5} 40 \mathrm{~kg} \cdot \mathrm{ha}^{-1}$ and $\mathrm{K}_{2} \mathrm{O} 60 \mathrm{~kg} \cdot \mathrm{ha}^{-1}$. Plant protection against diseases and pests was used in the whole experiment according to recommendations for the wheat.

\section{Experimental set-up}

Experimental treatments included herbicides: (i) MCPA + dicamba (Chwastox Turbo $340 \mathrm{SL}$ ), (ii) dicamba + triasulfuron (Lintur 70WG), (iii) florasulam +2,4-D (Mustang 306 SE) and biostimulants: (i) Kelpak SL (32,26\% algae Ecklonia maxima extract) and (ii) Asahi SL composed of nitrophenols (sodium ortho nitrophenol, sodium para nitrophenol, sodium 5-nitroguaiacolate).

These preparations were applied according to the following scheme:

1. Control (untreated plots);

2. MCPA + dicamba applied at the dose $600 \mathrm{~g}$ a.i $\cdot \mathrm{ha}^{-1}$ $+80 \mathrm{~g}$ a. $\mathrm{i} \cdot \mathrm{ha}^{-1}$ at the growth stage $\mathrm{BBCH} 30$;

3. Mixture of MCPA + dicamba+ Kelpak, applied at the dose $600 \mathrm{~g}$ a.i $\cdot \mathrm{ha}^{-1}+80 \mathrm{~g}$ a.i $\cdot \mathrm{ha}^{-1}+2 \mathrm{dm}^{3} \cdot \mathrm{ha}^{-1}$ at the growth stage $\mathrm{BBCH} 30$;

4. MCPA + dicamba applied at the dose $600 \mathrm{~g}$ a.i $\cdot \mathrm{ha}^{-1}$ $+80 \mathrm{~g}$ a.i ha $^{-1}$ at BBCH 30 followed by Kelpak applied three days later at the dose $2 \mathrm{dm}^{3} \cdot \mathrm{ha}^{-1}$;

5. Mixture of MCPA + dicamba + Asahi applied at the dose $600 \mathrm{~g}$ a.i $\cdot \mathrm{ha}^{-1}+80 \mathrm{~g}$ a.i $\cdot \mathrm{ha}^{-1}$ $+0.6 \mathrm{dm}^{3} \cdot \mathrm{ha}^{-1}$ at the growth stage BBCH 30 ;

6. $\mathrm{MCPA}+$ dicamba applied at the dose $600 \mathrm{~g}$ a.i $\cdot \mathrm{ha}^{-1}$ $+80 \mathrm{~g}$ a.i $\cdot \mathrm{ha}^{-1}$ at $\mathrm{BBCH} 30$ followed by Asahi applied three days later at the dose $0.6 \mathrm{dm}^{3} \cdot \mathrm{ha}^{-1}$;

7. Dicamba + triasulfuron applied at the dose $98.8 \mathrm{~g}$ a.i ha ${ }^{-1}+6.15 \mathrm{~g}$ a.i $\cdot \mathrm{ha}^{-1}$ at the growth stage BBCH 30 ; 8. Mixture of dicamba + triasulfuron + Kelpak applied at the dose $98.8 \mathrm{~g} \mathrm{a} . \mathrm{i} \cdot \mathrm{ha}^{-1}+6.15 \mathrm{~g}$ a.i $\cdot \mathrm{ha}^{-1}+$ $2 \mathrm{dm}^{3} \cdot \mathrm{ha}^{-1}$ at the growth stage BBCH 30 ;

9. Dicamba + triasulfuron applied at the dose $98.8 \mathrm{~g}$ a.i $\cdot \mathrm{ha}^{-1}+6.15 \mathrm{~g}$ a.i $\cdot \mathrm{ha}^{-1}$ at BBCH 30 followed by Kelpak applied three days later at the dose $2 \mathrm{dm}^{3} \cdot \mathrm{ha}^{-1}$; 10. Mixture of dicamba + triasulfuron + Asahi applied at the dose $98.8 \mathrm{~g}$ a.i ha $^{-1}+6.15 \mathrm{~g}$ a.i $\cdot \mathrm{ha}^{-1}+0.6 \mathrm{dm}^{3} \cdot \mathrm{ha}^{-1}$ at the growth stage $\mathrm{BBCH} 30$;

11. Dicamba + triasulfuron applied at the dose $98.8 \mathrm{~g}$ a.i $\cdot \mathrm{ha}^{-1}+6.15 \mathrm{~g}$ a.i ${ }^{-1} \mathrm{~h}^{-1}$ at BBCH 30 followed by Asahi applied three days later at the dose $0.6 \mathrm{dm}^{3} \cdot \mathrm{ha}^{-1}$;

12. Florasulam + 2,4-D applied at the dose $3.75 \mathrm{~g}$ a.i $\cdot \mathrm{ha}^{-1}+180 \mathrm{~g}$ a. $\mathrm{i} \cdot \mathrm{ha}^{-1}$ at the growth stage BBCH 30 ; 13. Mixture of florasulam $+2,4-\mathrm{D}+$ Kelpak applied at the dose $3.75 \mathrm{~g}$ a.i $\cdot \mathrm{ha}^{-1}+180 \mathrm{~g}$ a.i ha ${ }^{-1}+2 \mathrm{dm}^{3} \cdot \mathrm{ha}^{-1}$ at the growth stage $\mathrm{BBCH} 30$;

14. Florasulam $+2,4-\mathrm{D}$ applied at the dose $3.75 \mathrm{~g}$ a.i $\cdot \mathrm{ha}^{-1}+180 \mathrm{~g}$ a.i $\mathrm{ha}^{-1}$ at $\mathrm{BBCH} 30$ followed by Kelpak applied three days later at a dose $2 \mathrm{dm}^{3} \cdot \mathrm{ha}^{-1}$; 15. Mixture of florasulam $+2,4-\mathrm{D}+$ Asahi applied at 
the dose $3.75 \mathrm{~g}$ a.i $\cdot \mathrm{ha}^{-1}+180 \mathrm{~g}$ a.i $\cdot \mathrm{ha}^{-1}+0.6 \mathrm{dm}^{3} \cdot \mathrm{ha}^{-1}$ at the growth stage $\mathrm{BBCH} 30$;

16. Florasulam $+2,4-\mathrm{D}$ applied at the dose $3.75 \mathrm{~g}$ a.i $\cdot \mathrm{ha}^{-1}+180 \mathrm{~g}$ a.i $\cdot \mathrm{ha}^{-1}$ at BBCH 30 followed by Asahi applied three days later at the dose $0.6 \mathrm{dm}^{3} \cdot \mathrm{ha}^{-1}$.

\section{Parameters}

Treatments were conducted using a bicycle-mounted Victoria sprayer equipped with TeeJet 11002 VP sprayers using $200 \mathrm{dm}^{3}$ of spray liquid per ha, with operating pressure of $0.3 \mathrm{MPa}$. Temperature during the applications varied between $21-23^{\circ} \mathrm{C}$ depending on term and year of study.

\section{Observations}

The herbicide efficacy of the tested chemicals was assessed visually on 5th June 2014 and $15^{\text {th }}$ June 2015 , comparing the level of weed infestation with each of the weed species on every plot treated with the herbicide with the untreated plot. Efficacy against weeds was presented on a percentage scale, where $100 \%$ means complete control and $0 \%$ means no herbicide effect.

Systematic, visual assessments of the phytotoxic effect of the applied chemicals and their mixtures on spring wheat were conducted during the vegetation period. The thousand gain weight was assessed on the basis of five replications of 100 grains. Number of grains per ear was determined by twenty five ears randomly collected from each plot. Harvest was performed on $8^{\text {th }}$ August 2014 and $16^{\text {th }}$ August 2015 using Wintersteiger Classic plot combined. Grain yield was determined at $14 \%$ grain moisture and then calculated per surface area of 1 ha. The qualitative grain analysis was conducted with an InfratecTM 1241 Grain Analyser (FOSS).

The meteorological data got from a station located at the field experiment site (Falęcin, $\left.53^{\circ} 13^{\prime} 54^{\prime \prime} \mathrm{N}, 18^{\circ} 32^{\prime} 51^{\prime \prime} \mathrm{E}\right)$.

\section{Statistics}

The data on herbicide efficacy on the density, number of grains per ear, grain yield, weight of thousand grains and selected grain quality properties were subject to statistical analysis. The results of the Fisher test were evaluated at $1 \%$ and 5\% significance level. Upon discovering significant differences, a detailed comparison of the means using the Student's $t$-distribution test was performed in order to determine the lowest significant difference at a $5 \%$ significance level. It was decided to present the results separately for each year of the experiment because of completely different weather conditions during the years (Table 1).

\section{RESULTS}

\section{Weed control}

The weed control efficacy in both years of the study depended on the chemical composition of the tank mixture and the sensitivity of the weed species to the applied herbicide active substances. Adding Kelpak and Asahi biostimulants to the liquid containing selected herbicides had no effect on the biological efficacy against Chenopodium album, Galium aparine and Matricaria indora (Table 2). Results of the field studies showed a slight decline in the efficacy against Veronica agrestis and

Table 1 - Weather conditions during years of studies.

\begin{tabular}{|c|c|c|c|c|}
\hline \multirow[t]{2}{*}{ Month } & \multicolumn{2}{|c|}{-----------------------------------2014------------------------------------ } & \multicolumn{2}{|c|}{--------------------------------------2015------------------------------- } \\
\hline & Average day/night temperature $\left({ }^{\circ} \mathrm{C}\right)$ & Rainfall (mm) & Average day/night temperature $\left({ }^{\circ} \mathrm{C}\right)$ & Rainfall (mm) \\
\hline January & -2.7 & 44.8 & 2.0 & 32.5 \\
\hline February & 3.7 & 36.8 & 1.6 & 15.0 \\
\hline March & 7.5 & 74.6 & 6.3 & 34.5 \\
\hline April & 11.1 & 35.5 & 8.9 & 18.1 \\
\hline May & 13.6 & 81.1 & 12.7 & 35.0 \\
\hline June & 16.3 & 43.2 & 15.7 & 47.3 \\
\hline July & 21.9 & 60.8 & 18.9 & 121.5 \\
\hline August & 17.9 & 49.5 & 21.7 & 7.5 \\
\hline September & 15.1 & 25.2 & 14.5 & 25.7 \\
\hline Sum & - & 451.5 & - & 337.1 \\
\hline
\end{tabular}

Ciência Rural, v.48, n.11, 2018. 
Table 2 - Influence of herbicides and biostimulants Kelpak and Asahi on weed control in wheat.

\begin{tabular}{|c|c|c|c|c|c|c|}
\hline \multirow[b]{2}{*}{ Treatments } & \multirow[b]{2}{*}{ Herbicide dose $\left(\mathrm{a} . \mathrm{i} \cdot \mathrm{ha}^{-1}\right)$ Biostimulant dose $\left(\mathrm{dm}^{3} \mathrm{ha}^{-1}\right)$} & \multicolumn{5}{|c|}{---1\% } \\
\hline & & 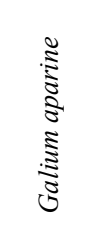 & 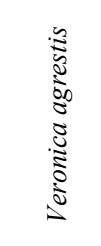 & 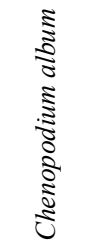 & 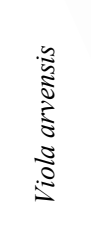 & 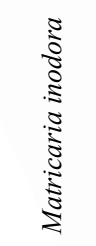 \\
\hline Untreated (No. plants $\cdot \mathrm{m}^{2}$ ) & - & 4.0 & 6.5 & 23.2 & 16.7 & 4.0 \\
\hline$(\mathrm{MCPA}+$ dicamba $)$ & $(600+80)$ & $100.0_{\mathrm{a}}$ & $91.3_{\mathrm{a}}$ & $100.0_{\mathrm{a}}$ & $89.8_{\mathrm{ab}}$ & $95.0_{\mathrm{a}}$ \\
\hline$(\mathrm{MCPA}+$ dicamba $)+$ Kelpak & $(600+80)+2.0$ & $100.0_{\mathrm{a}}$ & $86.5_{\mathrm{ab}}$ & $100.0_{\mathrm{a}}$ & $82.0_{\mathrm{ab}}$ & $97.5_{a}$ \\
\hline$(\mathrm{MCPA}+$ dicamba $) /$ Kelpak & $(600+80) / 2.0$ & $100.0_{\mathrm{a}}$ & $93.8_{\mathrm{a}}$ & $100.0_{\mathrm{a}}$ & $87.5_{\mathrm{ab}}$ & $92.5_{\mathrm{a}}$ \\
\hline$(\mathrm{MCPA}+$ dicamba $)+$ Asahi & $(600+80)+0.6$ & $100.0_{\mathrm{a}}$ & $87.5_{\mathrm{ab}}$ & $100.0_{\mathrm{a}}$ & $86.3_{\mathrm{ab}}$ & $91.3_{\mathrm{a}}$ \\
\hline$(\mathrm{MCPA}+$ dicamba $) /$ Asahi & $(600+80) / 0.6$ & $100.0_{\mathrm{a}}$ & $91.3_{\mathrm{a}}$ & $100.0_{\mathrm{a}}$ & $88.8_{\mathrm{ab}}$ & $91.3_{\mathrm{a}}$ \\
\hline (Dicamba+triasulfuron) & $(98.8+6.15)$ & $100.0_{\mathrm{a}}$ & $85.0_{\mathrm{ab}}$ & $93.8_{\mathrm{a}}$ & $89.3_{\mathrm{ab}}$ & $95.0_{\mathrm{a}}$ \\
\hline (Dicamba+triasulfuron)+Kelpak & $(98.8+6.15)+2.0$ & $100.0_{\mathrm{a}}$ & $80.0_{\text {abcd }}$ & $93.8_{a}$ & $93.5_{\mathrm{a}}$ & $100.0_{\mathrm{a}}$ \\
\hline (Dicamba+triasulfuron)/Kelpak & $(98.8+6.15) / 2.0$ & $97.5_{\mathrm{a}}$ & $86.3_{\mathrm{ab}}$ & $94.8_{a}$ & $.90 .0_{\mathrm{ab}}$ & $95.0_{\mathrm{a}}$ \\
\hline (Dicamba+triasulfuron) + Asahi & $(98.8+6.15)+0.6$ & $95.0_{\mathrm{a}}$ & $72.5_{\text {bcd }}$ & $95.0_{\mathrm{a}}$ & $90.8_{a}$ & $97.5_{\mathrm{a}}$ \\
\hline (Dicamba+triasulfuron)/Asahi & $(98.8+6.15) / 0.6$ & $100.0_{\mathrm{a}}$ & $87.5_{\mathrm{ab}}$ & $95.0_{\mathrm{a}}$ & $91.8_{\mathrm{a}}$ & $95.0_{\mathrm{a}}$ \\
\hline (Florasulam+2,4-D) & $(3.75+180)$ & $100.0_{\mathrm{a}}$ & $83.8_{\mathrm{abc}}$ & $97.5_{\mathrm{a}}$ & $84.5_{\mathrm{ab}}$ & $100.0_{\mathrm{a}}$ \\
\hline$($ Florasulam+2,4-D)+Kelpak & $(3.75+180)+2.0$ & $100.0_{\mathrm{a}}$ & $66.3_{\mathrm{cd}}$ & $99.8_{\mathrm{a}}$ & $75.0_{\mathrm{b}}$ & $100.0_{\mathrm{a}}$ \\
\hline$($ Florasulam+2,4-D)/Kelpak & $(3.75+180) / 2.0$ & $100.0_{\mathrm{a}}$ & $85.0_{\mathrm{ab}}$ & $99.8_{a}$ & $82.5_{\mathrm{ab}}$ & $100.0_{\mathrm{a}}$ \\
\hline$($ Florasulam $+2,4-\mathrm{D})+$ Asahi & $(3.75+180)+0.6$ & $100.0_{\mathrm{a}}$ & $65.0_{\mathrm{d}}$ & $99.5_{\mathrm{a}}$ & $55.0_{\mathrm{c}}$ & $98.8_{\mathrm{a}}$ \\
\hline$($ Florasulam+2,4-D)/Asahi & $(3.75+180) / 0.6$ & $100.0_{\mathrm{a}}$ & $80.0_{\mathrm{abcd}}$ & $99.5_{\mathrm{a}}$ & $82.5_{\mathrm{ab}}$ & $100.0_{\mathrm{a}}$ \\
\hline $\mathrm{LSD}_{0.05}$ & & Ns & 18.3 & ns & 15.1 & ns \\
\hline
\end{tabular}

$\mathrm{T} 1(+)$ means application as a tank mixture at BBCH 30 of wheat; T2 (/) means separate application 3 days after T1.

Viola arvensis after the application of mixtures of biostimulants with MCPA + dicamba and dicamba + triasulfuron herbicides. When combined with florasulam $+2,4-\mathrm{D}$, the tested biostimulants also caused a significant decline in the efficacy against these weed species.

\section{Wheat yield}

The yield level in both years of the study was related to weather conditions (rainfall) in each year of the study. In 2015, lower rainfall in the spring (March and April) had negative impact on the growth of spring wheat, resulting in a decrease in yielding.

In 2014, regardless of the method of application of the Kelpak biostimulant, an increase in the yielding of spring wheat, in comparison with the control, was observed. The analysis of the impact of each of the substances on the discussed parameter showed a slight decrease in the grain weight of spring wheat where MCPA + dicamba was applied, either separately or in a mixture, in comparison with the plots sprayed with the herbicide only (Table 3). There was a slight increase in the weight of the grains collected from plots sprayed with mixtures of the tested substances and biostimulant. The studies in 2015 reflected opposite results. The method of application of a biostimulant was reported to have no effect on the yield level of spring wheat (MCPA+ dicamba) or only slightly reduced the yield (when mixed with dicamba + triasulfuron or florasulam + 2,4-D) in comparison with separate application of the substances (Table 4).

The Asahi biostimulant, when combined with herbicides, did not significantly affect the weight of the grains (Table 3). Despite the lack of significant differences, a tendency for an increase in yielding was observed when substances were applied separately in both years. The statistical analyses did not show any significant differences between the different methods of biostimulant application.

In addition, the studies did not show any significant correlations between the application 
Table 3 - Influence of herbicides and biostimulants Kelpak and Asahi on weight of thousand grains and number of grains in ear of wheat.

\begin{tabular}{|c|c|c|c|c|c|}
\hline \multirow[b]{2}{*}{ Treatments } & \multirow[b]{2}{*}{$\begin{array}{c}\text { Herbicide dose }\left(\mathrm{a} . \mathrm{i} \cdot \mathrm{ha}^{-1}\right) \\
\text { Biostimulant dose }\left(\mathrm{dm}^{3} \cdot \mathrm{ha}^{-1}\right)\end{array}$} & \multicolumn{2}{|c|}{-Weight of thousand grains (g)-- } & \multicolumn{2}{|c|}{-----Number of grains in ear----- } \\
\hline & & & ---Experin & tal year-- & \\
\hline & & 2014 & 2015 & 2014 & 2015 \\
\hline Untreated & - & $37.93_{\mathrm{ab}}$ & $41.46_{\mathrm{bc}}$ & $28.9_{\mathrm{abc}}$ & $33.0_{\mathrm{a}}$ \\
\hline (MCPA+dicamba) & $(600+80)$ & $39.29_{\mathrm{ab}}$ & $42.24_{\mathrm{abc}}$ & $31.1_{\mathrm{a}}$ & $34.2_{\mathrm{a}}$ \\
\hline$(\mathrm{MCPA}+$ dicamba)+Kelpak & $(600+80)+2.0$ & $38.75_{\mathrm{ab}}$ & $43.95_{\mathrm{a}}$ & $26.0_{\mathrm{c}}$ & $33.9_{\mathrm{a}}$ \\
\hline$(\mathrm{MCPA}+$ dicamba $) /$ Kelpak & $(600+80) / 2.0$ & $38.61_{\mathrm{ab}}$ & $43.03_{\mathrm{ab}}$ & $28.4_{a b c}$ & $34.1_{\mathrm{a}}$ \\
\hline$(\mathrm{MCPA}+$ dicamba $)+$ Asahi & $(600+80)+0.6$ & $38.29_{\mathrm{ab}}$ & $41.87_{\mathrm{abc}}$ & $26.8_{\mathrm{bc}}$ & $34.2_{\mathrm{a}}$ \\
\hline$(\mathrm{MCPA}+$ dicamba $) /$ Asahi & $(600+80) / 0.6$ & $38.03_{\mathrm{ab}}$ & $42.83_{\mathrm{ab}}$ & $27.3_{\mathrm{abc}}$ & $34.8_{\mathrm{a}}$ \\
\hline (Dicamba+triasulfuron) & $(98.8+6.15)$ & $39.02_{\mathrm{ab}}$ & $42.35_{\mathrm{abc}}$ & $27.6_{\mathrm{abc}}$ & $32.6_{a}$ \\
\hline (Dicamba+triasulfuron) + Kelpak & $(98.8+6.15)+2.0$ & $39.61_{\mathrm{a}}$ & $42.17_{\mathrm{abc}}$ & $30.8_{\mathrm{ab}}$ & $32.0_{\mathrm{a}}$ \\
\hline (Dicamba+triasulfuron)/Kelpak & $(98.8+6.15) / 2.0$ & $39.97 \mathrm{a}$ & $42.44_{\mathrm{abc}}$ & $30.9 \mathrm{a}$ & $32.3_{\mathrm{a}}$ \\
\hline (Dicamba+triasulfuron)+Asahi & $(98.8+6.15)+0.6$ & $38.32_{\mathrm{ab}}$ & $42.74_{\mathrm{abc}}$ & $28.6_{\mathrm{abc}}$ & $31.1_{\mathrm{a}}$ \\
\hline (Dicamba+triasulfuron)/Asahi & $(98.8+6.15) / 0.6$ & $38.90_{\mathrm{ab}}$ & $42.12_{\mathrm{abc}}$ & $27.3_{\mathrm{abc}}$ & $31.4 \mathrm{a}$ \\
\hline (Florasulam+2,4-D) & $(3.75+180)$ & $38.09_{\mathrm{ab}}$ & $40.33_{c}$ & $27.7_{\mathrm{abc}}$ & $32.2_{\mathrm{a}}$ \\
\hline (Florasulam+2,4-D)+Kelpak & $(3.75+180)+2.0$ & $38.68_{\mathrm{ab}}$ & $41.65_{\mathrm{abc}}$ & $28.6_{\mathrm{abc}}$ & $32.0_{\mathrm{a}}$ \\
\hline$($ Florasulam+2,4-D)/Kelpak & $(3.75+180) / 2.0$ & $39.02_{\mathrm{ab}}$ & $41.03_{\mathrm{bc}}$ & $29.2_{\mathrm{abc}}$ & $32.4_{a}$ \\
\hline$($ Florasulam $+2,4-\mathrm{D})+$ Asahi & $(3.75+180)+0.6$ & $37.42_{\mathrm{b}}$ & $41.13_{\mathrm{bc}}$ & $28.5_{\mathrm{abc}}$ & $32.2_{\mathrm{a}}$ \\
\hline$($ Florasulam $+2,4-\mathrm{D}) /$ Asahi & $(3.75+180) / 0.6$ & $38.87_{\mathrm{ab}}$ & $41.75_{\mathrm{abc}}$ & $30.0_{\mathrm{abc}}$ & $33.1_{\mathrm{a}}$ \\
\hline $\operatorname{LSD}_{0.05}$ & & 2.06 & 2.42 & 4.1 & 4.0 \\
\hline
\end{tabular}

$\mathrm{T} 1(+)$ means application as a tank mixture at BBCH 30 of wheat; T2 (/) means separate application 3 days after T1.

method and the ear-bearing number of spikes, the number of grains per ear and the mass of 1000 grains (Table 4). The evaluation of the number of grains per ear and the mass of 1000 grains showed insignificant differences between the test objects; however, tendency to decrease in the number of grains in ears after the application of mixtures and an increase in the mass of 1000 grains after the application of biostimulants was recorded. The correlation analysis showed a significant impact of the different yield structure elements, mainly number of spikes, on the yield of spring wheat (Table 5).

\section{Grain quality traits}

Among the analyzed study variants in 2014 , the wheat grains from the plots treated with florasulam $+2,4$-Dherbicide exhibited the lowest content of protein (Table 6) and gluten, as well as low Zeleny sedimentation value (Table 7). When the herbicide was applied in combination with the Asahi biostimulant, the quality parameters of the grain improved.

The obtained results show that there was no significant correlation between the method of application of the biostimulant and the quality parameters of wheat grains. There was a tendency for a decrease in the quality of the grain (protein, gluten, Zeleny value) after the application of mixtures containing MCPA + dicamba, while there was positive impact in case of dicamba + triasulfuron herbicide. Different results were obtained when the biostimulants were used in combination with florasulam + 2,4-D (slight decrease in the parameters in the case of Kelpak and an increase in grain quality in the case of Asahi).

The grains from the 2015 harvest were of better quality than the grains from the 2014 harvest.

Regardless of the year of study, the analyzed tank mixtures were not reported to have any phytotoxic impact on the KWS Torridon spring wheat (data not given).

\section{DISCUSSION}

The two-year field studies showed that adding both Kelpak and Asahi biostimulants to the spray liquid containing MCPA + dicamba and dicamba + triasulfuron herbicides had no impact on the weed 
Table 4 - Influence of herbicides and biostimulants Kelpak and Asahi on number of spikes per $\mathrm{m}^{2}$ and yield of wheat.

\begin{tabular}{|c|c|c|c|c|c|}
\hline \multirow[b]{2}{*}{ Treatments } & \multirow[b]{2}{*}{$\begin{array}{c}\text { Herbicide dose }\left(\mathrm{a} . \mathrm{i} \cdot \mathrm{ha}^{-1}\right) \\
\text { Biostimulant dose }\left(\mathrm{dm}^{3} \mathrm{ha}^{-1}\right)\end{array}$} & \multicolumn{2}{|c|}{------Number of spikes/m²------ } & \multicolumn{2}{|c|}{---Yield $\left(t \cdot h^{-1}\right)$------- } \\
\hline & & & ----Exper & al year- & \\
\hline & & 2014 & 2015 & 2014 & 2015 \\
\hline Untreated & - & $564.0_{\mathrm{b}}$ & $328.7_{\mathrm{ab}}$ & $6.16_{\mathrm{cd}}$ & $4.49_{\mathrm{abcd}}$ \\
\hline (MCPA+dicamba) & $(600+80)$ & $598.7_{\mathrm{ab}}$ & $322.7_{\mathrm{ab}}$ & $7.27_{\mathrm{ab}}$ & $4.65_{\mathrm{abcd}}$ \\
\hline$(\mathrm{MCPA}+$ dicamba $)+$ Kelpak & $(600+80)+2.0$ & $652.0_{\mathrm{ab}}$ & $338.7_{\mathrm{ab}}$ & $6.54_{\mathrm{bcd}}$ & $5.03_{\mathrm{a}}$ \\
\hline$(\mathrm{MCPA}+$ dicamba $) /$ Kelpak & $(600+80) / 2.0$ & $564.0_{\mathrm{b}}$ & $337.3_{\mathrm{ab}}$ & $6.15_{\mathrm{cd}}$ & $4.95_{\mathrm{ab}}$ \\
\hline$(\mathrm{MCPA}+$ dicamba $)+$ Asahi & $(600+80)+0.6$ & $580.0_{\mathrm{ab}}$ & $304.7_{b}$ & $5.95_{d}$ & $4.37_{\mathrm{bcd}}$ \\
\hline$(\mathrm{MCPA}+$ dicamba $) /$ Asahi & $(600+80) / 0.6$ & $646.7_{\mathrm{ab}}$ & $328.0_{\mathrm{ab}}$ & $6.69_{\mathrm{abcd}}$ & $4.89_{\mathrm{abc}}$ \\
\hline (Dicamba+triasulfuron) & $(98.8+6.15)$ & $648.0_{\mathrm{ab}}$ & $319.3_{\mathrm{ab}}$ & $6.98_{\mathrm{abc}}$ & $4.39_{\mathrm{abcd}}$ \\
\hline (Dicamba+triasulfuron)+Kelpak & $(98.8+6.15)+2.0$ & $617.3_{\mathrm{ab}}$ & $335.3_{\mathrm{ab}}$ & $7.54_{a}$ & $4.53_{\mathrm{abcd}}$ \\
\hline (Dicamba+triasulfuron)/Kelpak & $(98.8+6.15) / 2.0$ & $589.3_{\mathrm{ab}}$ & $345.3_{\mathrm{ab}}$ & $7.23_{\mathrm{ab}}$ & $4.74_{\text {abcd }}$ \\
\hline (Dicamba+triasulfuron)+Asahi & $(98.8+6.15)+0.6$ & $564.0_{\mathrm{b}}$ & $318.7_{\mathrm{ab}}$ & $6.17_{\mathrm{cd}}$ & $4.23_{\mathrm{d}}$ \\
\hline (Dicamba+triasulfuron)/Asahi & $(98.8+6.15) / 0.6$ & $673.3_{\mathrm{a}}$ & $340.0_{\mathrm{ab}}$ & $7.13_{\mathrm{abc}}$ & $4.48_{\mathrm{abcd}}$ \\
\hline (Florasulam+2,4-D) & $(3.75+180)$ & $641.3_{\mathrm{ab}}$ & $330.0_{\mathrm{ab}}$ & $6.74_{\text {abcd }}$ & $4.27_{\mathrm{cd}}$ \\
\hline$($ Florasulam $+2,4-\mathrm{D})+$ Kelpak & $(3.75+180)+2.0$ & $649.3_{\mathrm{ab}}$ & $319.3_{\mathrm{ab}}$ & $7.17_{\mathrm{ab}}$ & $4.27_{\mathrm{cd}}$ \\
\hline$($ Florasulam+2,4-D)/Kelpak & $(3.75+180) / 2.0$ & $556.0_{\mathrm{b}}$ & $364.0_{\mathrm{a}}$ & $6.34_{b c d}$ & $4.83_{\text {abcd }}$ \\
\hline$($ Florasulam $+2,4-\mathrm{D})+$ Asahi & $(3.75+180)+0.6$ & $612.0_{\mathrm{ab}}$ & $351.3_{\mathrm{ab}}$ & $6.49_{\mathrm{bcd}}$ & $4.62_{\mathrm{abcd}}$ \\
\hline$($ Florasulam $+2,4-\mathrm{D}) /$ Asahi & $(3.75+180) / 0.6$ & $646.7_{\mathrm{ab}}$ & $342.7_{\mathrm{ab}}$ & $7.54 a$ & $4.73_{\mathrm{abcd}}$ \\
\hline $\mathrm{LSD}_{0.05}$ & & 106.6 & 51.1 & 0.99 & 0.65 \\
\hline
\end{tabular}

$\mathrm{T} 1(+)$ means application as a tank mixture at BBCH 30 of wheat; T2 (/) means separate application 3 days after T1.

control efficacy. Similar observations were published by KIERZEK et al. $(2013,2015)$ on the basis of sugar beet and corn experiments and GOLIAN et al. (2014) with regard to Asahi or AlfaMax biostimulant mixes with metribuzin in carrot. According to SOLTANI et al. (2015 a), biostimulant-herbicide mixes may vary in terms of their impact on the weed control efficacy against weeds. They showed no correlation (Crop Booster biostimulant mixed with bromoxynil or MCPA) and improved efficacy against Amaranthus retroflexus (a mixture of Crop Booster or RR SoyBooster biostimulants with a glyphosate liquid) or a decrease in the efficacy against Setaria viridis (Crop Booster mixed with glyphosate and thiencarbazone-methyl). Similary, when florasulam $+2,4-\mathrm{D}$ was applied in combination with Kelpak and Asahi biostimulants, a decrease in the control of Veronica agrestis and Veronica arvensis was observed in both years of the study in comparison with separate application or herbicide-only application.

A different view on the subject was presented by DOMARADZKI et al. (2015) on the

Table 5 - Correlation coefficients between yield forming traits and yield of wheat.

\begin{tabular}{|c|c|c|c|c|}
\hline \multirow[t]{3}{*}{ Variable } & \multicolumn{4}{|c|}{ 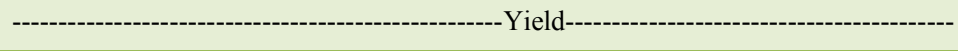 } \\
\hline & \multicolumn{2}{|c|}{ 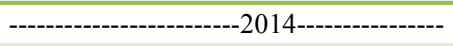 } & \multicolumn{2}{|c|}{ - } \\
\hline & $\mathrm{P}<0.05$ & $\mathrm{P}<0.01$ & $\mathrm{P}<0.05$ & $\mathrm{P}<0.01$ \\
\hline Number of spikes per $\mathrm{m}^{2}$ & $0.56487^{*}$ & $0.56487^{* *}$ & $0.55549^{*}$ & $0.55549^{* *}$ \\
\hline Weight of thousand grains & $0.451895^{*}$ & $0.451895^{* *}$ & $0.309823^{*}$ & 0.309823 \\
\hline Number of grains in ear & $0.425804^{*}$ & $0.425804^{* *}$ & $0.505907^{*}$ & $0.505907^{* *}$ \\
\hline
\end{tabular}

*significance level. 
Table 6 - Influence of herbicides and biostimulants Kelpak and Asahi on protein and starch content in wheat grains.

\begin{tabular}{|c|c|c|c|c|c|}
\hline \multirow{2}{*}{ Treatments } & \multirow{2}{*}{$\begin{array}{c}\text { Herbicide dose }\left(\mathrm{a} . \mathrm{i} \cdot \mathrm{ha}^{-1}\right) \\
\text { Biostimulant dose }\left(\mathrm{dm}^{3} \mathrm{ha}^{-1}\right)\end{array}$} & \multicolumn{2}{|c|}{-------Protein in grains (\%)------ } & \multicolumn{2}{|c|}{------Starch in grains (\%)----- } \\
\hline & & & -----Exp & vear. & \\
\hline & & 2014 & 2015 & 2014 & 0015 \\
\hline Untreated & & 1012 & & 7082 & 6707 \\
\hline . & $\cos ^{-}$ & $10.1 J_{a b c}$ & $12.5 J_{\mathrm{abcd}}$ & $70.02 \mathrm{ab}$ & $0 \% .9 / \mathrm{abc}$ \\
\hline$(\mathrm{MCPA}+$ dicamba $)$ & $(600+80)$ & $10.53_{\mathrm{abc}}$ & $12.60_{\text {abcd }}$ & $70.90_{\mathrm{ab}}$ & $67.78_{\mathrm{abc}}$ \\
\hline$(\mathrm{MCPA}+$ dicamba $)+$ Kelpak & $(600+80)+2.0$ & $10.60_{\mathrm{ab}}$ & $12.13_{\mathrm{bcd}}$ & $70.98_{\mathrm{ab}}$ & $68.48_{\mathrm{abc}}$ \\
\hline$(\mathrm{MCPA}+$ dicamba $) /$ Kelpak & $(600+80) / 2.0$ & $10.58_{\mathrm{ab}}$ & $11.93_{\mathrm{bcd}}$ & $70.83_{\mathrm{ab}}$ & $68.60_{\mathrm{abc}}$ \\
\hline$(\mathrm{MCPA}+$ dicamba $)+$ Asahi & $(600+80)+0.6$ & $10.10_{\mathrm{abc}}$ & $11.60_{\mathrm{cd}}$ & $71.08_{\mathrm{ab}}$ & $68.88_{\mathrm{ab}}$ \\
\hline$(\mathrm{MCPA}+$ dicamba $) /$ Asahi & $(600+80) / 0.6$ & $10.30_{\mathrm{abc}}$ & $12.50_{\mathrm{abcd}}$ & $70.88_{\mathrm{ab}}$ & $67.80_{\mathrm{abc}}$ \\
\hline (Dicamba+triasulfuron) & $(98.8+6.15)$ & $10.63_{\mathrm{ab}}$ & $12.60_{\mathrm{abcd}}$ & $70.63_{\mathrm{ab}}$ & $68.00_{\mathrm{abc}}$ \\
\hline (Dicamba+triasulfuron)+Kelpak & $(98.8+6.15)+2.0$ & $9.90_{\mathrm{abc}}$ & $12.70_{\text {abcd }}$ & $71.33_{\mathrm{ab}}$ & $67.50_{\mathrm{abc}}$ \\
\hline (Dicamba+triasulfuron)/Kelpak & $(98.8+6.15) / 2.0$ & $10.38_{\mathrm{abc}}$ & $12.63_{\mathrm{abcd}}$ & $70.83_{\mathrm{ab}}$ & $68.33_{\mathrm{abc}}$ \\
\hline (Dicamba+triasulfuron)+Asahi & $(98.8+6.15)+0.6$ & $10.73_{\mathrm{a}}$ & $13.38_{\mathrm{abc}}$ & $70.28_{b}$ & $67.30_{\mathrm{abc}}$ \\
\hline (Dicamba+triasulfuron)/Asahi & $(98.8+6.15) / 0.6$ & $10.50_{\mathrm{abc}}$ & $11.20_{\mathrm{d}}$ & $70.60_{\mathrm{ab}}$ & $69.83_{\mathrm{a}}$ \\
\hline$($ Florasulam+2,4-D) & $(3.75+180)$ & $9.63_{\mathrm{bc}}$ & $14.33_{\mathrm{a}}$ & $71.93_{a}$ & $65.93_{\mathrm{c}}$ \\
\hline$($ Florasulam $+2,4-\mathrm{D})+$ Kelpak & $(3.75+180)+2.0$ & $9.68_{\mathrm{bc}}$ & $13.53_{\mathrm{abc}}$ & $71.10_{\mathrm{ab}}$ & $66.73_{\mathrm{bc}}$ \\
\hline$($ Florasulam+2,4-D)/Kelpak & $(3.75+180) / 2.0$ & $9.80_{\mathrm{abc}}$ & $13.73_{\mathrm{ab}}$ & $71.83_{\mathrm{a}}$ & $66.50_{\mathrm{bc}}$ \\
\hline (Florasulam $+2,4-\mathrm{D})+$ Asahi & $(3.75+180)+0.6$ & $10.23_{\mathrm{abc}}$ & $13.50_{\mathrm{abc}}$ & $70.78_{\mathrm{ab}}$ & $66.58_{\mathrm{bc}}$ \\
\hline (Florasulam+2,4-D)/Asahi & $(3.75+180) / 0.6$ & $9.53_{\mathrm{c}}$ & $13.50_{\mathrm{abc}}$ & $71.93_{\mathrm{a}}$ & $67.13_{\mathrm{abc}}$ \\
\hline $\mathrm{LSD}_{0.05}$ & & 1.03 & 1.97 & 1.44 & 2.88 \\
\hline
\end{tabular}

$\mathrm{T} 1(+)$ means application as a tank mixture at BBCH 30 of wheat; T2 (/) means separate application 3 days after T1.

basis of sugar beet field observations. According to the author, adding Asahi and Kelpak biostimulants to the spray liquid containing reduced doses of herbicides does not change herbicide efficacy and, in some variants of the study, improves the control of Polygonum aviculare. The authors of the study showed an efficacy decrease of mixtures against Amaranthus retroflexus only in the case of a greater reduction of the herbicide doses.

There has been a number of publications describing the positive impact of biostimulants on the growth and development of crop plants (KHAN et al., 2011a; KHAN et al., 2011b; MATYSIAK et al., 2012; JANNIN et al., 2013; LASKOWSKA et al., 2013; GUGAŁA et al., 2017). According to some of the authors, these substances not only increase the yielding but also neutralize the adverse impact of weather conditions and plant protection chemicals and reduce the occurrence of diseases in crop plants (MACIEJEWSKI et al., 2007; -SAWICKA \& KROCHMAL-MARCZAK, 2009 BALABANOVA et al., 2016; CONSTANTIN et al., 2016). Depending on the composition of the mixture and the year of the field experiments, the tested substances and their mixtures had varied effects on the yield of spring wheat. Adding Kelpak biostimulant in the year with heavier rainfall (2014) resulted in a statistically insignificant yield increase, while using the other biostimulant (Asahi) resulted in a slight decrease in the yield. In 2015, regardless of the type of biostimulant used (Kelpak or Asahi), mixed applications produced worse results in terms of yield and grain weight than when the substances were applied separately. There was no significant correlations between the use of biostimulants and the yield. Contrarily, SOLTANI et al. (2015 a), KIERZEK et al. (2013 and 2015) and DOMARADZKI et al. (2015) indicated that herbicide-biostimulant mixtures had no significant impact on the yield of winter wheat, oats, corn and sugar beet. However, SOLTANI et al. (2015 a) indicated a slight increase in the yield of winter wheat and corn after the application of such mixtures. A similar opinion was presented by KOSTADINOWA et al. (2016) on the basis of experiments on sunflower and ELMETWALLY (2016) on the basis of experiments on Vicia faba var. equina. CONSTANTIN et al. (2016) presented a different opinion, indicating an increase 
Table 7 - Influence of herbicides and biostimulants Kelpak and Asahi on gluten and Zeleny value in grain of wheat.

\begin{tabular}{|c|c|c|c|c|c|}
\hline \multirow[b]{2}{*}{ Treatments } & \multirow{2}{*}{$\begin{array}{l}\text { Herbicide dose }\left(\mathrm{a} . \mathrm{i} \cdot \mathrm{ha}^{-1}\right) \\
\text { Bostimulant dose }\left(\mathrm{dm}^{3} \mathrm{ha}^{-1}\right)\end{array}$} & \multicolumn{2}{|c|}{--------Gluten in grains (\%)------- } & \multicolumn{2}{|c|}{-----------Zeleny value----------- } \\
\hline & & & -Experi & l year-- & \\
\hline & & 2014 & 2015 & 2014 & 2015 \\
\hline Untreated(No. plants $\cdot \mathrm{m}^{2}$ ) & & 50 & & . & 2010 \\
\hline & $(600+80)$ & $22.00 \mathrm{ab}$ & 30.00 abcd & $20.15 \mathrm{abc}$ & 31.00 abcd \\
\hline (IVCPA+dicamba) & $(000+80)$ & $23.73 \mathrm{ab}$ & $30.08 \mathrm{abcd}$ & $23.30_{\mathrm{ab}}$ & $36.28 \mathrm{abcd}$ \\
\hline$(\mathrm{MCPA}+$ dicamba $)+$ Kelpak & $(600+80)+2.0$ & $23.98 \mathrm{ab}$ & $28.80 \mathrm{bcd}$ & $24.03 \mathrm{a}$ & 33.58 bcd \\
\hline$(\mathrm{MCPA}+$ dicamba $) /$ Kelpak & $(600+80) / 2.0$ & $23.78_{\mathrm{ab}}$ & 27.98 bcd & $23.20_{\mathrm{ab}}$ & $31.63 \mathrm{bcd}$ \\
\hline$(\mathrm{MCPA}+$ dicamba $)+$ Asahi & $(600+80)+0.6$ & $22.48 \mathrm{ab}$ & $26.53 \mathrm{~cd}$ & $21.38 \mathrm{abc}$ & $29.03 \mathrm{~cd}$ \\
\hline$(\mathrm{MCPA}+$ dicamba $) /$ Asahi & $(600+80) / 0.6$ & $22.90_{\mathrm{ab}}$ & 29.80 abcd & $21.78_{\mathrm{abc}}$ & 36.00 abcd \\
\hline (Dicamba+triasulfuron) & $(98.8+6.15)$ & $23.90_{\mathrm{ab}}$ & 30.18 abcd & $23.60_{\mathrm{ab}}$ & 36.93 abcd \\
\hline (Dicamba+triasulfuron)+Kelpak & $(98.8+6.15)+2.0$ & $21.93 \mathrm{ab}$ & 30.90 abcd & $20.33 \mathrm{abc}$ & 38.58 abcd \\
\hline (Dicamba+triasulfuron)/Kelpak & $(98.8+6.15) / 2.0$ & $23.00_{\mathrm{ab}}$ & 30.60 abcd & $21.90 \mathrm{abc}$ & 37.98 abcd \\
\hline (Dicamba+triasulfuron)+Asahi & $(98.8+6.15)+0.6$ & 24.08 a & $32.90 \mathrm{abc}$ & $23.38_{\mathrm{ab}}$ & 42.58 abcd \\
\hline (Dicamba+triasulfuron)/Asahi & $(98.8+6.15) / 0.6$ & $23.70_{\mathrm{ab}}$ & $25.63 \mathrm{~d}$ & $23.28_{\mathrm{ab}}$ & $27.90_{d}$ \\
\hline$($ Florasulam+2,4-D) & $(3.75+180)$ & $21.23 \mathrm{~b}$ & $36.30_{\mathrm{a}}$ & $18.58 \mathrm{bc}$ & $51.33 \mathrm{a}$ \\
\hline$($ Florasulam $+2,4-\mathrm{D})+$ Kelpak & $(3.75+180)+2.0$ & $21.40_{\mathrm{ab}}$ & $33.70_{\mathrm{ab}}$ & $18.88_{\mathrm{bc}}$ & $45.00_{\mathrm{ab}}$ \\
\hline$($ Florasulam $+2,4-\mathrm{D}) /$ Kelpak & $(3.75+180) / 2.0$ & $21.68_{\mathrm{ab}}$ & $34.23_{\mathrm{ab}}$ & $19.90 \mathrm{abc}$ & $46.60_{\mathrm{ab}}$ \\
\hline$($ Florasulam $+2,4-\mathrm{D})+$ Asahi & $(3.75+180)+0.6$ & $22.80_{\mathrm{ab}}$ & $33.63 \mathrm{ab}$ & $21.70_{a b c}$ & $44.18 \mathrm{abc}$ \\
\hline$($ Florasulam+2,4-D)/Asahi & $(3.75+180) / 0.6$ & $21.23_{b}$ & $33.68 \mathrm{ab}$ & $18.03_{\mathrm{c}}$ & $45.53_{\mathrm{ab}}$ \\
\hline $\mathrm{LSD}_{0.05}$ & & 2.77 & 6.60 & 5.08 & 15.86 \\
\hline
\end{tabular}

$\mathrm{T} 1(+)$ means application as a tank mixture at BBCH 30 of wheat; T2 (/) means separate application 3 days after T1.

in soybean yield resulted from the reduction in yield losses due to herbicide damage. Another argument for the use of herbicide-biostimulant mixtures is the neutralizing effect of such mixtures on the damages in crop plants caused by herbicide active substances. The above opinion was published on the basis of field experiments on soybean (glyphosate used in combination with Fertiactyl PÓS); however, the beneficial effect of the use of mixtures has limited damage regeneration capabilities. In case of severe symptoms of phytotoxic effects of herbicides on the crop (glyphosate applied in combination with lactophenol or chlorimuron), the beneficial effects of the combined use of the substances cannot fully compensate the damage caused by the mixtures used. A different view on the subject was presented by SOLTANI et al. (2015 b), indicating that the method of application had no impact on the crops. Our studies did not show any positive effects of the method of application of the tested mixtures due to the lack of herbicide-induced phytotoxic symptoms on KWS Torridon spring wheat. In case of bread cereal crops, the grain quality parameters not only affect the yield but also their grind ability. Quality properties of the grain depend on the variety, weather and agrotechnical conditions. Air temperature has significant impact on the protein content in cereal crops. A comparative analysis of the results of the studies conducted in two vegetation seasons with different weather conditions showed that the grains from the 2014 harvest exhibited lower protein and gluten content in comparison with 2015. In 2014, the period between stem formation and heading (May and June) was marked by higher air temperatures than in the corresponding period in 2015. Increase in air temperature in the period between stem formation and heading results in the reduction of protein content in winter wheat grain (EREKUL and KÖHN, 2006). However, MATYSIAK et al. (2012), and KIERZEK et al. (2015) stated that bio stimulants have no impact on the quality parameters of the crops (oilseed rape, maize, sugar beet). A different view on the subject was presented by DOMARADZKI et al. (2015) on the basis of sugar beet field studies. According to the authors, when the biostimulants were applied in combination with herbicides, it resulted in an increase in the sugar content in sugar beet roots (especially Kelpak). A similar thesis was proposed by ZARZECKA et al. (2017), indicating an increase in the polyphenol 
content in potato tubers after using a biostimulant. Our studies did not show any significant impact of the tested substances, whether applied jointly or separately, on selected quality properties of cereal grains. However, the studies showed that there was a tendency for an improvement of grain quality after the application of the tested biostimulants in combination with dicamba + triasulfuron herbicide or a decline in grain quality in the case of biostimulant mixtures with MCPA + dicamba. Different grain quality results were obtained when the biostimulants were used in combination with florasulam $+2,4-\mathrm{D}$ (a slight improvement of grain quality in the case of Asahi and a decline in grain quality in the case of Kelpak). In addition to weather conditions and genetic conditions, the quality of cereal grains can be modified by herbicides applied during the vegetation period. GIL et al. (2003), confirmed that propoxycarbazonesodium and sulfosulfuron have a varying impact on the flour grindability, resulting, in some years, in a slight decline in the protein and wet gluten content, as well as the sedimentation index. Our studies also reflected a significant reduction of the protein and gluten content and Zeleny sedimentation value after the application of florasulam $+2,4-\mathrm{D}$, regardless of the herbicide application method in 2014.

In the present study we demonstrated possibilities of application of herbicides mixed with biostimulants. Besides of obvious economic benefits of this manner of application, further advantages can be revealed in enhancement of yield quantity and quality i.e. increasing of grain mass as well as proteins and gluten content in grains. However, except of these profits proved in our study, also adverse effects on herbicide efficacy expressed by poorer control of mid-sensitive weeds have appeared. The most important abiotic factor influenced biostimulants and some herbicides in the field are weather conditions, and for that reason effects of mixtures (herbicide and biostimulant) may slightly vary depending on the year. We concluded that the proper application of herbicides and biostimulants affects the potential to improve wheat yields. However, further research on this point should be conducted, providing more precise information.

\section{ACKNOWLEDGEMENTS}

This study was the part of the Statutory Research Programme of the Institute of Plant Protection - National Research Institute in Poland. The project 'Evaluation of biological activity of plant growth regulators and biostimulants in cereals' (No. HET-08/1.3.3) was supported by the Polish Ministry of Science and Higher Education.

\section{DECLARATION \\ OF \\ CONFLICTING INTERESTS}

The authors declare no conflict of interest. The founding sponsors had no role in the design of the study; in the collection, analyses, or interpretation of data; in the writing of the manuscript, and in the decision to publish the results.

\section{AUTHORS' CONTRIBUTIONS}

All authors contributed equally for the conception and writing of the manuscript. All authors critically revised the manuscript and approved of the final version.

\section{REFERENCES}

BALABANOVA, D.A. et al. Photosynthetic performance of the imidazolinone resistant sunflower exposed to single and combined treatment by the herbicide imazamox and an amino acid extract. Frontiers in Plant Science, v.7, p.1559, 2016. Available from: $<$ https://doi.org/10.3389/fpls.2016.01559>. Accessed: Mar. 23, 2018.

CALVO, P. et al. Agricultural uses of plant biostimulants. Plant and Soil, v.383, p.3-41, 2014. Available from: $<$ https://doi. org/10.1007/s11104-014-2131-8>. Accessed: Mar. 23, 2018.

CRAIGIE, J.S. et al. Seaweed extract stimuli in plant science and agriculture. Journal of Applied Phycology, v.23, p.371-393, 2011. Available from: <https://doi.org/10.1007/s10811-010-9560-4>. Accessed: Mar. 23, 2018.

CONSTANTIN, J. et al.Prevention of yield losses caused by glyphosate in soybeans with biostimulant. African Journal of Agricultural Research, v.11, n.18, p.1601-1607, 2016. Available from: <https://doi.org/10.5897/AJAR2016.10809>. Accessed: Mar. 23, 2018.

DOMARADZKI, K. et al. Ocena skuteczności mieszaniny herbicydów i biostymulatorów w uprawie buraka cukrowego. 2015. Przemys! Chemiczny, v.94, n.5, p.787-792, 2015. Available from: $<$ http://dx.doi. org/10.15199\%2F62.2015.5.28>. Accessed: Mar. 23, 2018.

DU JARDIN, P. Plant biostimulants: Definition, concept, main categories and regulation. Scientia Horticulturae, v.196, p.3-14, 2015. Available from: <https://doi.org/10.1016/j. scienta.2015.09.021>. Accessed: Mar. 23, 2018.

EL-METWALLY, I. M. Efficiency of some weed control treatments and some bio-stimulants on growth, yield and its components of faba bean and associated weeds. International Journal of PharmTech Research, v. 9, n.12, p. 165-174, 2016. Available from: $\quad<$ http://sphinxsai.com/2016/ph_vol9_no12/1/(165-174) V9N12PT.pdf $>$. Accessed: Mar. 23, 2018.

EREKUL, O.; KÖHN, W.Effect of weather and soil conditions on yield components and bread making quality of winter wheat (Triticum aestivum L.) and winter Triticale (Triticosecale Wittm.) varieties in North East Germany. Journal of Agronomy and Crop Science, v.192, p.452-464, 2006. Available from: <https://doi. org/10.1111/j.1439-037X.2006.00234.x>. Accessed: Mar. 23, 2018.

GIL Z., et. al. Wartość technologiczna ziarna pszenicy ozimej W zależności od stosowanych herbicydów. Progress in Plant Protection, v.43, n.2, p.683-685, 2003. 
GOLIAN, J. et al. The assessment of herbicides application with biostimulants and adjuvants in carrot (Daucus carota L.) Progress in Plant Protection, v.54, n.2, p.167-173, 2014. Available from: $<$ http:// dx.doi.org/10.14199/ppp-2014-027>. Accessed: Mar. 23, 2018.

GUGAŁA, M. et al. Wpływ herbicydów i biostymulatorów wzrostu na ograniczenia zachwaszczenia i plonowanie ziemniaka jadalnego. Fragmenta Agronomica, v.34, n.4, p.59-66, 2017. Available from: <http://www.up.poznan.pl/pta/pdf/2017/FA\%20 34(4)\%202017\%20Gugala.pdf>. Accessed: Mar. 23, 2018.

JANNIN, L. et al. Brassica napus growth is promoted by Ascophyllum nodosum (L.) Le Jol. seaweed extract: microarray analysis and physiological characterization of $\mathrm{N}, \mathrm{C}$, and $\mathrm{S}$ metabolisms. Journal of Plant Growth Regulation, v.32, p.3152, 2013. Available from: <https://doi.org/10.1007/s00344-0129273-9>. Accessed: Mar. 23, 2018.

KIERZEK, R. et al. Effect of biostimulator Aminoplant mixtures with herbicides on sugar beet yield and quality. Progress in Plant Protection, v.53, n.3, p.621-626, 2013. Available from: <http:// www.progress.plantprotection.pl/?node_id=35\&lang=pl\&ma $\mathrm{id}=631>$. Accessed: Mar. 23, 2018.

KIERZEK, R. 2015. Effect of biostimulator Aminoplant mixtures with terbuthylazine and bromoxynil (Zeagran 340 SE) on herbicidal effect and yield of maize. Progress in Plant Protection, v.55, n.2, p.164-169, 2015. Available from: <https://doi.org/10.14199/ppp2015-027>. Accessed: Mar. 23, 2018.

KHAN, W.,et al. Seaweed extracts as biostimulants of plant growth and development. Journal of Plant Growth Regulation, v.28, p.386-399, 2009. Available from: <https://doi.org/10.1007/ s00344-009-9103-x>. Accessed: Mar. 23, 2018.

KHAN, W.,et al. Bioassay to detect Ascophyllum nodosum extractinduced cytokinin-like activity in Arabidopsis thaliana. Journal of Applied Phycology, v.23, p.409-414, 2011 a. Available from: $<$ https:// doi.org/10.1007/s10811-010-9583-x>. Accessed: Mar. 23, 2018.

KHAN, W.,et al.Influence of alginate oligosaccharides on growth, yield and alkaloid production of opium poppy (Papaver somniferum L.). Frontiers in Agriculture in China, v.5, p.122127, 2011b. Available from: <https://doi.org/10.1007/s11703-0101056-0>. Accessed: Mar. 23, 2018.

KOSTADINOWA, S., et al. Sunflower productivity in response to herbicide diflufenican (Pelican $50 \mathrm{SC}$ ) and foliar fertilizing. Agriculture \& Food, v.4,p.122-128, 2016. Available from: $<$ https:// www.scientific-publications.net/get/1000020/1465221139539601. pdf $>$. Accessed: Mar. 23, 2018.

LASKOWSKA, H. et al. The effect of bulb size and applicationmethod of Asahi SL biostimulator on the growth and yield of Alium moly L. Acta Agrobotanica, v.66, n.1, p. 89-94, 2013. Available from: $<$ https://doi.org/10.5586/aa.2013.010>. Accessed: Mar. 23, 2018.
MACIEJEWSKI, T. et al. Influence of biostymulator Asahi SL i Atonik SL on qualitative tubers of potatoes. Journal of Research and Applications in Agricultural Engineering, v.52, n.3, p.109112, 2007. Available from: <http://yadda.icm.edu.pl/baztech/ element/bwmeta1.element.baztech-article-BAR0-0031-0059>. Accessed: Mar. 23, 2018.

MATYSIAK, K. et al. Wpływ wyciągu z alg morskich Ecklonia maxima (Kelpak SL) na rośliny rzepaku ozimego. Oilseed Crops, v.33, n.1, p.81-88, 2012. Available from: <http://yadda.icm.edu.pl/ yadda/element/bwmeta1.element.agro-46d749cf-b7e0-4ecb-9eb4c53328f0dbe5>. Accessed: Mar. 23, 2018.

PRZYBYSZ, A. et al. Stimulatory effect of Asahi SL on selected plant species. Acta Scientiarum Polonorum Hortotum Culturus, v.9, p.53-64, 2010. Available from: <https://www. cabdirect.org/cabdirect/abstract/20103213144>. Accessed: Mar. 23, 2018.

PRZYBYSZ, A. et al. Biological mode of action of a nitrophenolates-based biostimulant: case study. Frontiers in Plant Science, v.5, p.713, 2014. Available from: $<$ https://doi. org/10.3389/fpls.2014.00713>. Accessed: Mar. 23, 2018.

SAWICKA, B.; KROCHMAL - MARCZAK, B. Wpływ stosowania nawozu dolistnego Insol 7 i bioregulatora Asahi SL na zdrowotność bulw kilku odmian ziemniaka. Annales Universitis Mariae Curie - Skłodowska Lublin, v.64, n.2, p. 29- 38, 2009. Available from: <http://wydawnictwo.up.lublin.pl/annales/ Agricultura/2009/2/05.pdf >. Accessed: Mar. 23, 2018.

SOLTANI, N. et al. Effect of biostimulants added topostemergence herbicides in corn, oats and winter wheat. Agricultural Sciences 6: 527-534, 2015a. Available from: <http://dx.doi.org/10.4236/ as.2015.65052>. Accessed: Mar. 23, 2018.

SOLTANI, N., et al. Responses of dry bean to biostimulants added to postemergence herbicides. Agricultural Sciences, v.6, p.1023-1032, 2015b. Available from: <http://dx.doi.org/10.4236/ as.2015.69097>. Accessed: Mar. 23, 2018.

STRIK, W.A. et al.Cytokinins in macroalgae. Plant Growth Regulation, v.41, p.13-24, 2003. Available from: $<$ https://doi. org/10.1023/A:1027376507197>. Accessed: Mar. 23, 2018.

VERKLEIJ F.N. Seaweed extracts in agriculture and horticulture: a review. Biological Agriculture \& Horticulture, v.8, p.309-324, 1992. Available from: $<$ https://doi.org/10.1080/01448765.1992.97 54608>. Accessed: Mar. 23, 2018.

ZARZECKA, K. et al. The effect of herbicides and biostimulants on polyphenol content of potato (Solanum tuberosum L.) tubers and leaves. Journal of the Saudi Society of Agricultural Sciences, 2017 (online). Available from: <https://doi.org/10.1016/j. jssas.2017.02.004>. Accessed: Mar. 23, 2018. 